\title{
Savings and investment equality does not prevail according to Keynesian definitions
}

\author{
Tamás Bánfi \\ Department of Finance, \\ Corvinus University of Budapest
}

\begin{abstract}
Aside from the general government and the non-resident sector, textbooks on macroeconomics uniformly define the following correlation under the terms investment and saving: $I=S$. The $I=S$ equality is naturally and legitimately interpreted by macroeconomic textbooks almost without exception as the equality between intended investments and intended savings, because the equality - if we accept it - is not only a definitive identity, but generally the outcome of market mechanisms that take time. Keynes's first critic was Robertson who claimed that "his analysis corresponded to $<<$ what common-sense proclaims (even to the simple-minded) to be the essence of the matter; namely, the power possessed by the public and by the monetary authority to alter the rates of income flow - the former by putting money into and out of store, the latter by putting it into and out of existence. $<<$ Thus, in his definition, $I=S+(A+B)$, in which $A$ is new money and $B$ is reactivated idle balances. " Robertson's comment could have been addressed with a simple correction, and the tool used for funding the expansion of state (public) investments, i.e. the government deficit financed by the creation of new money, is a consistent element of the theoretical framework.
\end{abstract}

Keywords: investment, saving, Keynes, Robertson

\section{INTRODUCTION: THE KEYNESIAN THEORY}

Aside from the general government and the non-resident sector, textbooks on macroeconomics uniformly define the following correlation under the terms investment and saving:

$$
\text { Actual saving = Investment, }
$$

that means,

$I=S$.

If we add the general government and the non-resident sector to the analysis as net exports, then national investment is the amount of domestic investment $(I)$ and net exports $(X)$, and actual national savings is the amount of private savings (PS) comprising the savings of households and corporations, plus government savings (GS) (Samuelson-Nordhaus, 2005, pp. 394-395):

$$
I+X=P S+G S
$$

An equation identical in content but expressed in a different form is (Hall-Taylor, 1997, pp. 72-76):

$$
I=P S+G S+T S
$$

where instead of net exports increasing investments, the third factor increasing national savings is capital inflows (TS) assuming net imports. 
The origin of the $I=S$ equality is clear. According to Keynes, "Provided it is agreed that income is equal to the value of current output, that current investment is equal to the value of that part of current output which is not consumed, and that saving is equal to the excess of income over consumption [...] the equality of saving and investment necessarily follows. In short,

Income $=$ value of output $=$ consumption + investment

Saving $=$ income - consumption.

Therefore saving = investment. " (Keynes, 1935, p. 47)

The $I=S$ equality is naturally and legitimately interpreted by macroeconomic textbooks almost without exception as the equality between intended investments and intended savings, because the equality - if we accept it - is not only a definitive identity, but generally the outcome of market mechanisms that take time. The specification should not come as a surprise, because Keynes had stressed that "the amount of saving is an outcome of the collective behaviour of individual consumers and the amount of investment of the collective behaviour of individual entrepreneurs" (Keynes, 1935, p. 47), so the $I=S$ equality is the result of mass dual-sided individual decisions, and consequently does not define a status, but is rather an outcome assuming a process.

The previous statement can be demonstrated easily based on the internal structure of the $I=S$ equality. There is a partial equality within the $I=S$ equality, where the equality is an identity. A saving and an investing individual may be the same person or corporation, in which case the equality is only an identity. This case is referred to as self-financing. Let us assume that the investor issues a bond, which those with the intention to save subscribe to; the subscribers' savings are therefore the source of financing, so the investment may materialise as the outcome of this time-consuming process, which gives rise to the $I=S$ partial equality that differs from the identity.

If the intended consumption becomes actual consumption with a lag, the intended investment becomes an actual investment, and concurrently, the intended saving becomes an actual saving, the I = S equality also expresses an equilibrium situation, as opposed to being only an equality during the delayed period, without being associated with equilibrium.

\section{ALVIN HANSEN'S REVIEW AND EXPLANATIONS}

In The General Theory, in the context of a new conceptual system and using new designations, Keynes refutes Say's Law, explains the causes of economic crises and expounds on the toolset that can be used to avoid or at least mitigate crises, and the economic process that can be created using this toolset. His conceptual system is based on maintaining employment or mitigating the decline in employment to the greatest extent possible, which fiscal policy can achieve by effectively boosting demand or at least maintaining it at its current level.

The comments on the cumbersome style of demonstration and the presentation of opinions contradicting debatable assertions do not detract from the economic significance of The General Theory. He could allow himself the luxury of leaving editing and stylisation to future generations. The first and direct example of this is Alvin Hansen's A Guide to Keynes, a study guide, and indirect solutions come in the form of Keynesian works of economics generally accepting Keynesian theory but offering corrections on some of its points.

Hansen justifies, explains and corrects. Hansen states that "Saving" is a mere residual. The whole Keynesian analysis could be developed without ever using the word "saving." Indeed in the concluding sentence of Chap. 6, Keynes announced that "the conception of the propensity to 
consume will, in what follows, take the place of the propensity or disposition to save." But Keynes in fact continued to use the word "saving" throughout his book. And in the discussion of the savings-investment problem, which followed the publication of the General Theory, a vast confusion arose. (Hansen, 1953, p. 59)

Almost 80 years after the publication of The General Theory, it may appear as if this matter has been addressed. However, this appearance is deceptive.

The importance of distinguishing between equality and equilibrium has become widely accepted. Saving and investment could be equal at all times, but the equality is not always an equilibrium as well. Due to the time requirement of market processes, intended consumption/saving/investment only becomes actual consumption/saving/investment with a certain lag, so the equality is not yet equilibrium in the course of the delay. According to Hansen "investment and saving are always equal, they are not always in equilibrium." (Hansen, 1953, p. 59)

Hansen draws a surprising conclusion, which can only be explained by his bias towards Keynes. Following the above quote, two pages later Hansen writes the following on the saving and investment equality: „A second, but related, confusion arose because many of Keynes” critics found it difficult to reconcile the equality of saving and investment with the undeniable fact that a part of the funds going into investment often is financed form bank credit (new money) or from idle balances. How then, it was asked, could saving equal investment?" (p. 62)

The two objections should be set apart, the second one (a portion of the amount allocated to investments is covered from amounts unused until that point) being, in my opinion, less relevant and easily corrected. The same does not hold true for investment financed with "new money", which has theoretical significance and is not a change requiring a simple correction, but a statement that calls into question the saving and investment equality as a general correlation.

Keynes's first critic was Robertson (1933, p. 411), who claimed that "his analysis corresponded to $<<$ what common-sense proclaims (even to the simple-minded) to be the essence of the matter; namely, the power possessed by the public and by the monetary authority to alter the rates of income flow - the former by putting money into and out of store, the latter by putting it into and out of existence. $<<$ Thus, in his definition, $I=S+(A+B)$, in which $A$ is new money and $B$ is reactivated idle balances. " (The quote is included by Hansen as a footnote on p. 62)

Hansen continuously treats and interprets Robertson's two counterarguments together. In his view, The point is that, in Robertson's way of looking at the problem, the new money plus the reactivated idle balances are thought to be in addition to income. In the Keynesian definition the new funds, having in fact been expanded in the current period, swell the current oncome, making it larger than it would otherwise have been. And that part of current income which is not spent on consumers' goods is in fact saved. The Keynesian saving (from current income) would thus exceed Robertsonian saving (from yesterday's income). The difference between the two is the expenditure made from new money and from reactivated idle balances. Keynesian $S$ = Robertsonian $\mathrm{S}+(\mathrm{A}+\mathrm{B}) . "$ (p. 62)

What is acceptable by Hansen: "Keynesian $S=$ Robertsonian $S+(A+B)$." What is not acceptable: new money is added to national income, and the portion of the thus increased current national income that is not spent on consumer goods will be actual saving. National income cannot be created directly by creating new money, and likewise, national income 
cannot be lost by destroying money. New money increases the cash flow that flows from the income not spent on consumption, i.e. from savings, to the market of capital goods. One of the components of cash flow is the amount of money from current income not spent on consumption, i.e. current savings, and the other component is new money created through money creation. If investments are financed from self-financing or from current savings through financial system intermediation, the income spent on saving and consumption, i.e. income that is the sum of these two components, is also expressed in monetary terms. It can be linked to the income flow stemming from savings expressed in forints and the created new money increasing the former. New money may also be a source of financing equal to the amount of saving remaining from current income. This is possible, but is not the only option.

When can new money be a source of financing stemming from current savings? The simplest answer is when savings are in the form of cash. Cash savings are stored in the institutional sector's petty cash reserves, and cannot be intermediated by an institution for investments, however, commercial banks can create money in an equivalent amount by extending loans, or creating new money to make up for the savings stored in petty cash reserves, supplementing the current savings present on the investment market.

An answer can be given describing a more complex case alongside (but not instead of) cash savings stored in petty cash reserves. With the development of the money and capital market, the saving entity can choose from a number of savings schemes that do not provide sources of financing for the investment market. These include savings instruments opting for foreign money and capital markets (capital exports).

One necessary supplementary option and requirement for the creation of new money is well known in Hungarian financial and political literature. Miklós Riesz (1979, p. 242) argues that the third system of financial intermediation of savings towards material accumulation is "supplementary money creation equivalent to the amount of savings accumulating in the form of money: banks issue supplementary quantities of money equal to the amount of long-term money accumulation by providing (money-creating) loans for material accumulation."

As students of Professor Riesz, two colleagues from the Department of Finance and I wrote our book published in 1986, which contains a statement identical in content with the above citation, referencing Miklós Riesz: supplementary money creation "expresses that under a fiat money system, there is no need for savings money, only for refraining from demand, and information expressing the intention of saving (and the expected duration thereof). This means that if somebody keeps their money at home, their savings can also be utilised in the same way - without them knowing about it - as those held in savings banks. However, the economic subjects affected have more accurate information about the latter type of savings, so the interest paid on savings deposits can be regarded as a fee paid partly for refraining from demand, and partly for providing information on the intention to save - rather than a fee paid for using the money (Bánfi-Sulyok-Száz, 1986, p. 21).

If we are familiar with and accept the money creation necessary for the saving and investment equality, the magnitude of which can perhaps be estimated at macro level, on a micro level it loses its macroeconomic content and significance in the context of commercial banks' financing decisions. Banks decide and satisfy corporations' investment loan requirements not on the basis of the stock of savings generated during the period at issue, but based on future return founded on future investment market demand. In terms of home building, the return and thus banks' decisions will depend on future solvent home buyers, and similarly, on future solvent vehicle buyers in the realm of vehicle production. If a private company or the state intends to 
build a nuclear power plant, which features perhaps the highest credit requirements and the longest period of return, the grounds for a reasoned bank decision can only be future energy demand and alternative energy prices.

What are the arguments in favour of the saving and investment equality? One argument keeping investment market prices unchanged - can be mentioned, but is debatable. In practice, there is no total capacity utilisation, and the utilisation of surplus capacities does not necessarily entail a price increase. On a theoretical level, price increases are an inevitable effect if the size and change in capital good prices defines that of consumer goods, or if there is no link between capital good and consumer good prices, and they are defined independently of each other in distinct manners.

The interpretation of the saving and investment equality and equilibrium cannot be fully distinguished from capital good price changes, or only if we assume constant prices. Following the logic of Keynes and Hansen, this is what we will do, but we cannot ignore the Keynesian dilemma. Prior to writing and publishing The General Theory, Keynes published A Treatise on Money (1930), in which he defines the price level of consumer and capital goods (pp. 131-134). Although he does define them, he also states that they are only formalities, identities (p. 130). In light of the above, it may come as a surprise that in The General Theory, Keynes revokes the correlations provided for the interpretation of the general price level, specifically, he deems them unsuitable for quantitative analysis (Keynes, 1935, p. 32).

\section{KEYNES'S INSISTENCE ON THE SAVING AND INVESTMENT EQUALITY}

Robertson's first article was published in September 1933, his second in November 1936, while Keynes's The General Theory was published in 1936, and his response in September 1939. According to the chronology of the publications, Keynes could have corrected his work based on Robertson's critique, but instead, he refuted Robertson's opinion in 1939 and maintained his own theory, supplementing it on certain points.

Hansen claims that Keynes agreed with Robertson on the fact that the funds available for current investment could be stated in terms of "prior saving" plus "dishoarding and credit expansion." He pointed out, however, that "the amount of saving which is taking place the same time as the investment" must be exactly equal to that investment. "Saving at the prior date cannot be greater than the investment at that date. ... Dishoarding and credit expansion provides not an alternative to increased saving, but a necessary preparation for it. It is the parent, not the twin, of increased saving." (p. 63).

The weakest point of Keynes's argument: "Dishoarding and credit expansion provides not an alternative to increased saving, but a necessary preparation for it. It is the parent, not the twin, of increased saving." (p. 63) Preparing a new saving (whether large or small) is the precursor to activating previous dishoarding and the new money of money creation, but national income, investment, consumption and savings are flow-type categories, their dimension being money/time.

The consumption and saving stemming from the investment during a selected period - no matter how long - are not necessarily realised and generated during the same period, but due to the time requirement of the investment and depending on the speed of consumption are necessarily carried over to the following period(s). If we use traditional statistical recording as an example, the saving "born" of the investment featuring a money/year dimension can be generated either fully or partially during the same period (if the investment starts at the beginning of the current year and is short), but is also generated in the following 
period (begins towards the end of the current year and does or does not stretch on to the following period).

Hansen states that, "here it is evident that Keynes recognized the formal accuracy of the Robertsonian definitions. He noted that the Robertsonian prior saving plus dishoarding and credit creation was equal to his own current saving and also that the Robertsonian approach involved period analysis which envisaged the process of capital formation "as taking place over a period of time subject to time-lags of undetermined length." (p .63.)

Hansen also serves the truth. Both definitions are good, and are useful depending on the purpose of analysis: "The Keynesian way of looking at the problem appeals indeed to common sense, no less than the Robertsonian. The additional sales (due to the new funds thrown into the market) increase the current incomes of business units and of employed factors. Out to these enlarged current incomes, a greater saving is made. These savings are made out of income earned in the current period of production, and the people making these savings would not like to be told that they are not really savings. From this standpoint the definition appeals as much to common sense as the Robertsonian definition, which insists that the term "saving" must be restricted to that part of yesterday's income which is not currently spent on consumers' goods." (p. 63.)

For the sake of accuracy, a minor remark must be added. The creation of new money may also occur at a point close to the end of the selected period, and the investment market demand stemming from the new money may stretch on to the next period. In this case, new money $\left(\mathrm{A}^{*}\right)$ equivalent to the quantity of demand stretching over to the next period must be subtracted [I = $\left.\mathrm{S}+\left(\mathrm{A}-\mathrm{A}^{*}\right)+\mathrm{B}\right]$ and added to the money created during the following period $\left[\mathrm{I}=\mathrm{S}+\left(\mathrm{A}+\mathrm{A}^{*}\right)+\right.$ $\mathrm{B}]$.

\section{CONCLUSION OF THE DEBATE}

1. Here it is evident that Keynes recognized the formal accuracy of the Robertsonian definitions., i.e. "that the Robertsonian prior saving plus dishoarding and credit creation was equal to his own current saving" (Hansen, 1965, p. 63)

2. If the national income of a specific period (one calendar year) can be divided into consumer and capital goods, and if the amount of national income of that specific period not spent on consumption constitutes the savings of the period, then the investments of the specific period are not equal to the savings of the specific period.

3. In short: if national income and savings pertain to a specific period, then

$\mathrm{A}=$ created, new money,

$$
\mathrm{I}=\mathrm{S}+(\mathrm{A}+\mathrm{B}) \text {, where }
$$

$\mathrm{B}=$ money accumulated earlier that has been reactivated,

which means,

$\mathrm{I} \neq \mathrm{S}$.

\section{"FURTHER CONSIDERATIONS ON THE MEANING OF SAVING AND INVESTMENT"}

What could be the reason behind Keynes's rigid rejection? Did he have any professional consideration besides vanity? Could it have violated the consistency of his school of thought, or weakened its premise?

It is worth taking another look at Hansen's statement: "Saving is a mere residual. The whole Keynesian analysis could be developed without ever using the word saving (Hansen, p. 76). If "The decisions to consume and the decisions to invest between them determine incomes" 
(Keynes, 1935, p. 47), and savings are merely a residual element, then the investment = savings expression can be written on the basis of formal logic, but has no economic relevance, it is just a tautology. Hanson does everything to explain Keynes's sentences, but nevertheless admits several times that "Keynes is wrong". In this case, however, the cardinal point of Keynes's entire school of thought seems to be affected.

According to Keynes, there is no investment without saving, and no saving without investment, which is true by definition if both are a portion of income not used for consumption. The saving and investment equality is true, but only ex post, because intended saving and investment are not necessarily equal ex ante and therefore equilibrium cannot be assumed with certainty. The ex post equality is the joint outcome of intended and unintended investment, and intended and unintended savings, which cannot and does not necessarily have to be referred to as equilibrium. Adjustment beyond the intended level materialises through goods or warehouse inventories (Ohlin, 1944; Lindahl, 1939).

Saving is the key to Keynes's theory of interest, where interest is defined based on the correlation between transactional, prudent and speculative money demand, but not independently of income.

In The General Theory, Keynes - whether in response to critiques or independently thereof returns to the conceptual explanation of saving. "The prevalence of the idea that saving and investment, taken in their straightforward sense, can differ from one another, is to be explained, I think, by an optical illusion due to regarding an individual depositor's relation to his bank as being a one-sided transaction, instead of seeing it as the two-sided transaction which it actually is. It is supposed that a depositor and his bank can somehow contrive between them to perform an operation by which savings can disappear into the banking system so that they are lost to investment, or, contrariwise, that the banking system can make it possible for investment to occur, to which no saving corresponds. But no one can save without acquiring an asset, whether it be cash or a debt or capital-goods; and no one can acquire an asset which he did not previously possess, unless either an asset of equal value is newly produced or someone else parts with an asset of that value which he previously had. In the first alternative there is a corresponding new investment: in the second alternative someone else must be dissaving an equal sum." (Keynes, 1935; p. 59) The second alternative is clear, but the first one is not; Keynes provides a specific, clear, but unacceptable explanation to the "new money, new investment" alternative a few rows later. "It is true that an unexpected increase of investment in a particular direction may cause an irregularity in the rate of aggregate saving and investment which would not have occurred if it had been sufficiently foreseen. It is also true that the grant of the bank-credit will set up three tendencies - (1) for output to increase, (2) for the marginal product to rise in value in terms of the wage-unit (which in conditions of decreasing return must necessarily accompany an increase of output), and (3) for the wage-unit to rise in terms of money (since this is a frequent concomitant of better employment); and these tendencies may affect the distribution of real income between different groups. But these tendencies are characteristic of a state of increasing output as such, and will occur just as much if the increase in output has been initiated otherwise than by an increase in bank-credit." (Keynes, 1935; pp. 59-60)

Keynes's train of thought is clear and straightforward. The quantity of money created by the banking system is invested by the borrower, output increases driven by this input, along with the value of the marginal product and wage unit expressed in monetary terms. Income increases and consumption also changes (presumably rises) through shifts in prices and wages, and the saving and investment equality is achieved at a higher level based on the 
change in income not spent on consumption. The same occurs, argues Keynes, "if the increase in output has been initiated otherwise than by an increase in bank-credit." (Keynes, 1935; p. $60)$.

The description and the explanations are clear, and would be acceptable in a framework of limited space and unlimited time. However, income, consumption, investment and saving can only apply to one specific period. Saving is a portion of the income generated during a specific period that is not spent on consumption, just like the investment and saving of a specific period are linked to the income for that same period. The traditional choice of period is one year, which may be deemed sufficiently long or, conversely, too short, but in no way can we assume that the periods stretching between investment decisions and the actual time of commissioning will always fall within a one-year time span. Moreover, the year is not an arbitrary 12 months, but the period between January and December, because national statistics calculate and publish national income between calendar years. If they do not fit within this time interval, then the items "carried over" from the previous year's saving are added to the savings of the current year, and the newly created money advanced for funding investments during the current year will not generate output during the current year, but only in the next or, rarely, in the second or third subsequent year. Keynes's text in chapter 6 of The General Theory specifies the definitions of income, investment and saving with respect to a specific period, and not independently thereof, but fails to factor in the dimension of time when returning to the concepts and responding to critiques. Income, investment and saving without a period cannot be interpreted, as they are unmeasurable in their quantity.

If it is true (and I think it is) that according to Keynes, consumption and saving are approximately a constant part of income, then income is defined by investment, but investment does not depend on saving, but rather on the marginal efficiency of capital, and through it, on expectations and interest rate. The interest rate is shaped by the money supply and liquidity requirement, which are not independent of the intention to save. The aim is to increase employment and the final objective is to achieve full employment, which can be achieved through sufficient investment, partly through public investments and partly through private investments. The Keynesian train of thought does not require the savings and investment equality, investments do not depend on savings, moreover, public investments are independent of savings and can be funded with monetary instruments to a greater degree than the state's classic revenues. The above-stated train of thought can be sustained even if after the definitions stated in Keynes's The General Theory, "income is equal to the value of current output, current investment is equal to the value of that part of current output which is not consumed", he would have abandoned the definition "saving is equal to the excess of income over consumption..." in response to the criticisms, and not concluded that "the equality of saving and investment necessarily follows" (Keynes, 1935, p. 47).

Keynes's insistence on the definition of saving is not a mandatory element of the theoretical framework of the existence of the investment $=$ saving correlation stemming from the definition, and could have been left out. We can and must agree with Hansen that saving can be interpreted as a residual and could have been omitted. If Keynes does not provide a separate definition of saving, it is not a necessary consequence of the theoretical framework of the saving and investment equality, and Robertson's comment could have been addressed with a simple correction, and the tool used for funding the expansion of state (public) investments, i.e. the government deficit financed by the creation of new money, is a consistent element of the theoretical framework. 


\section{References}

ANDRÉADES, A. (1924): History of the Bank of England, London

BAMBERGER BÉLA (1890): A valuta-kérdés az Észak-Amerikai Egyesült-Államokban. Révai Kiadó, Budapest

BÁNFI T.-HAGELMAYER I. (1989): Pénzelmélet és pénzügypolitika. Közgazdasági és Jogi Könyvkiadó, Budapest

BuchanAN, J. M. (1992): Piac, Állam, alkotmányosság. Közgazdasági és Jogi Könyvkiadó, Budapest

FARAGó MIKSA (1911): A Kossuth-bankók kora. Nyugat Kiadó, Budapest

FöLDES BÉLA (1912): Az államháztartástan. Grill Könyvkiadó, Budapest

FRIEDMAN, M. (1986): Infláció, munkanélküliség, monetarizmus, Közgazdasági és Jogi Könyvkiadó, Budapest

HАYЕK, F. A. (1991): Út a szolgasághoz. Közgazdasági és Jogi Könyvkiadó, Budapest

HomonNAY FARKAS (1947): Banktörténet. Officina, Budapest

KEYNES, J. M. (1965): A foglalkoztatottság, a kamat és a pénz általános elmélete. Közgazdasági és Jogi Könyvkiadó, Budapest

KöZGAZDASÁGI ENCIKLOPÉDIA. Athenaeum, 1929. Budapest

Leroy-BeAulieu, P. (1879): Pénzügytan I-IV. kötet. MTA Könyvkiadó, Budapest

Musgrave, R. A.-Musgrave, P. B. (1994): Public finance in theory and practice. McGraw-Hill

OLSON, M. (1987): Nemzetek felemelkedése és hanyatlása. Közgazdasági és Jogi Könyvkiadó, Budapest

ÓvÁRI PAPP ZoLTÁN (1926): A jegybankok viszonya az államhoz. Grill Könyvkereskedés, Budapest

Sмітн, A. (1776): An inquiring into the nature and causes of the wealth of nations. Edinburgh

STIEGLER, G. J. (1989): Piac és állami szabályozás. Közgazdasági és Jogi Könyvkiadó, Budapest 